\title{
SIMULASI PEMODELAN SISTEM LAYANAN GFR BERBASIS LOGIKA FUZZY PADA BUFFER SWITCH DI JARINGAN ATM
}

\author{
Rendy Munadi ${ }^{1}$, Sar Sardy $^{2}$, Dadang Gunawan ${ }^{3}$ \\ ${ }^{1}$ Jurusan Teknik Elektro, Sekolah Tinggi Teknologi Telkom, Bandung \\ ${ }^{2,3}$ Jurusan Teknik Elektro, Universitas Indonesia, Kampus Baru, Depok. \\ 1' rendymunadi@bdg.centrin.net.id, ${ }^{2}$ ssardy@ rad.net.id, ${ }^{3}$ guna@yexa.eng.ui.ac.id
}

\begin{abstract}
Abstrak
Paper ini membahasan mekanisme pengendalian manajemen buffer dalam mengimplementasikan layanan Guaranteed Frame Rate (GFR) pada Jaringan ATM berbasis logika fuzzy yang dikenal sebagai Fuzzy Fair Buffer Allocation (FFBA). Mekanisme ini lebih fleksibel, mudah diimplementasikan dan memproses penerimaan, pengalokasian dan pembuangan sel yang masuk pada buffer sesuai sifat First Input First Output (FIFO), serta menjamin Minimum Cell Rate (MCR) bagi trafik TCP/IP di jaringan ATM. Sebagai parameter dalam simulasi ini, seperti ukuran buffer sisa dan jumlah sel terkirim yang mampu menunjukkan bahwa FFBA memberikan jaminan MCR, total throughput sistem yang lebih dari penggunaan mekanisme konvensional dan maksimum buffer occupancy, dapat dicapai dengan meningkatnya beban trafik prioritas tinggi.
\end{abstract}

Kata kunci: layanan GFR, TCP/IP, Fuzzy Fair Buffer Allocation (FFBA), switch ATM

Abstract

This paper will discuss a mechanism for buffer management control to implement the ATM Guaranteed Frame Rate (ATM-GFR) Service based on fuzzy logic, which is called Fuzzy Fair Buffer Allocation (FFBA). The mechanism provides a more flexible, easily implementation to process the admitted, discarded, and allocated of cells in the FIFO buffer, which guarantees the Minimum Cell Rate (MCR) to TCP/IP traffic in the ATM Networks. The simulation on some parameters such as the rest of buffer size and the amount of sending cells indicates that the FFBA provides a minimum rate (MCR), also the total throughput of the system can more above the usage of conventional mechanism and maximum of buffer occupancy can be achieved with high priority traffic load increase.

Keywords: GFR service, TCP/IP, Fuzzy Fair Buffer Allocation (FFBA), ATM switch

\section{Pendahuluan}

Berkembangnya teknologi jaringan data kecepatan tinggi menuntut lahirnya inovasi-inovasi baru sehingga setiap layanan yang ditawarkan pada pelanggan mempunyai kualitas yang terbaik. Elemen Jaringan data kecepatan tinggi seperti di jaringan ATM adalah switch ATM itu sendiri, disamping link yang menghubungkannya.. Lahirnya teknologi masa depan tidak lepas dari komponen ini, sehingga penelitian-penelitian lebih lanjut terus dilakukan guna mendapatkan kinerja jaringan yang optimal dan mempunyai biaya yang rendah $[1,6]$.

Perkembangan terakhir menunjukkan bahwa trafik pengguna internet sangat menakjubkan, oleh karena itu perlu solusi yang tepat sehingga kegagalan koneksi dan kelambatan waktu layanan dapat dikurangi, atau dengan kata lain pengguna internet merasa mendapatkan kepuasan yang baik dari penyelenggara jaringan.

Trafik internet secara makro berupa trafik data sehingga dapat dipandang sebagai trafik terpaketisasi dengan membentuk segmen-segmen TCP dengan Maximum Segment Size (MSU) yang ditentukan oleh Maximum Transmission Unit (MTU) dari lapis penghubung elemen jaringan.
Layanan GFR seepenuhnya dirancang untuk paketpaket TCP pada lapis ATM Adaptation Layer 5 (AAL5) dengan melalui tingkat-tingkat seperti policing, manajemen buffer dan scheduling [1-3].

Pengguna dapat mengirimkan paket-paketnya yang berisi sel-sel yang ditandai atau berprioritas rendah (bit $C L P=1$ ) dan sel-sel yang tidak ditandai atau berprioritas tinggi (bit $\mathrm{CLP}=0$ ). Suatu frame dibangun dsri sel-sel ysng mempunyai nilai CLP yang sama. Hanya frame-frame yang berprioritas tinggi yang mendapatkan jaminan Minimum Cell Rate (MCR). Mekanisme penandaan tersebut sangat penting, sehingga jaringan dapat terhindar dari kondisi kongesti. Terdapat dua operasi yang penting pada layanan GFR sebagai bagian dari mekanisme yaitu : (1) penentuan occupancy buffer dan (2) penempatan sel-sel dalam sebuah antrian. Oleh karena itu problem yang sering muncul adalah bagaimana meningkatkan utilitas pada kondisi ruang buffer terbatas, sehingga lebih efisien [2,4,5,8].

Pada metode konvensional sistem pengendalian data masuk biasanya dengan dropping policy yang bergantung pada Buffer Occupancy (BO) dan mengatur jumlah sel yang antrian di buffer. Proses penerimaan, penempatan dan pembuangan sel di buffer ditentukan oleh batas ambang atas dan batas 
ambang bawah Oleh karena itu metode ini tidak adaptive terhadap perubahan beban trafik yang sewaktu-waktu berubah dengan cepat, sehingga besar throughput yang dihasilkan mengalami penurunan.[3][4]

Karena itu, dipaparkan suatu metode kendali berbasis logika fuzzy (FFBA) yang merupakan bagian dari manajemen buffer, sehingga dapat meningkatkan kinerja layanan GFR pada Jaringan ATM. Metode ini relatif menjamin kecepatan minimum untuk kebutuhan koneksi user ke jaringan dan total throughput sistem lebih besar dibanding metode non-fuzzy (konvensional) [9,10].

Didalam paper ini dilakukan tinjauan simulasi dengan parameter input seperti koneksi virtual (Virtual Channel) sejumlah lima buah terhadap kedua metode diatas, dengan membandingkan karakteristik dan total throughput yang dihasilkan. Pembangkitan trafik dengan distribusi Poisson dimodelkan terhadap semua pola kedatangan paket, sehingga analisa dan perhitungan dapat dilakukan. Program simulasi dibuat dengan bahasa pemrograman Delphi.

\section{Sistem Layanan GFR Berbasis Logika Fuzzy pada Buffer Switch di Jaringan ATM}

\subsection{ATM dan Layanan GFR}

ATM adalah suatu teknologi jaringan yang mampu melakukan pengiriman informasi berkecepatan tinggi, dengan pengguna yang berkomunikasi melalui jaringan dalam ukuran sel yang tetap. ATM menggunakan alokasi lebar pita (bandwidth) yang dinamis, yaitu bandwith dialokasikan pada pengguna sesuai dengan trafik kontrak (QoS) yang disepakati lebih dulu.

Berikut adalah konsep dasar teknologi ATM:

a. Semua informasi dibawa dalam bentuk unit data dengan panjang yang tetap yang disebut sebagai sel. Setiap sel terdiri dari 53 oktet atau bytes. Lima byte pertama berisi cell-header dan 48 byte sisanya berisi payload atau information field. Header berfungsi untuk mengindentifikasikan sel dari satu sambungan virtual (virtual connection) yang sama, dan melakukan routing.

b. Bersifat connection-oriented, sebelum informasi dikirimkan dari terminal menuju jaringan, yaitu pada fase pembangunan hubungan, harus dicek lebih dahulu apakah jaringan mampu atau tidak menyediakan sumber daya jaringan. Jika sumber tidak mencukupi, hubungan tersebut akan ditolak, tetapi jika sumber yang tersedia cukup untuk memberikan akses, maka permintaan hubungan akan diterima.

c. Tidak ada koreksi error atau flow control pada link-by-link basis.

d. Menggunakan prinsip asynchronous timedivision multiplexed atau statistical TDM (Time Division Multiplexed).
Beberapa kategori layanan didefenisikan dalam Standar ATM untuk mendukung kebutuhan setiap aplikasi, yaitu: Constant Bit Rate (CBR), Real-time Variable Bit Rate (Rt-VBR), Non real-time Variable Bit Rate (Nrt-VBR), Available Bit Rate (ABR), Unspecified Bit Rate (UBR) dan Guaranteed Frame Rate (GFR).

Layanan GFR didefinisikan untuk mendukung aplikasi-aplikasi non real-time dan memperkenalkan frame AAL-5, serta melakukan pembuangan pada level frame. Oleh karena itu, layanan ini dikatakan juga sebagai layanan frame-based dengan rate yang terjamin. Layanan GFR memungkinkan pengguna untuk memperoleh suatu layanan minimum rate saat jaringan mengalami kongesti, dan dapat mengirim pada rate yang lebih tinggi jika resources tersedia. Contoh aplikasi layanan GFR adalah frame relay internetworking dan seluruh aplikasi layanan Unspecified Bit Rate (UBR).

GFR menggunakan AAL-5 untuk membuat batasan-batasan frame terlihat dalam ATM layer. Dengan menggunakan AAL5, layanan GFR secara penuh didisain khusus untuk paket-paket TCP. Berikut akan dijelaskan metode pengendalian antrian yang meliputi metode konvensional dan metode berbasis logika fuzzy.

\subsection{Metode Konvensional}

Kendali antrian dengan metode konvensional seperti terlihat pada Gambar 1, dijelaskan bahwa kendali dilakukan dengan mengatur penempatan antrian pada buffer masing-masing $\mathrm{VC}$ berdasarkan mekanisme policing yang berbasis FIFO [2,3]. Mekanisme policing bergantung pada Buffer Occupancy (BO) yang mengatur jumlah sel antrian di buffer, yaitu :

a. Jika BO < LBO, maka semua sel dapat memasuki buffer

b. Jika $\mathrm{LBO}<\mathrm{BO}<\mathrm{HBO}$, maka semua sel yang ditandai dengan bit CLP=1 akan dibuang.

c. Jika $\mathrm{BO}>\mathrm{HBO}$, maka hanya sel terakhir dengan bit CLP=0 sebagai sel yang tidak ditandai yang diterima buffer, sel-sel dengan bit CLP=1 akan selalu dibuang lebih dahulu.

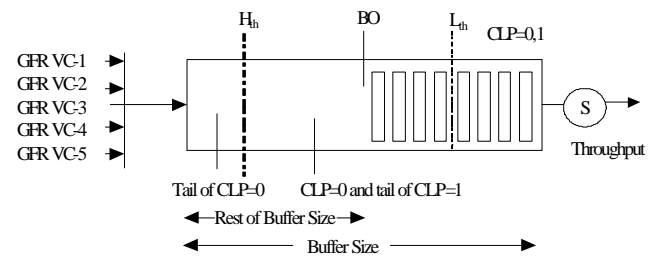

Gambar 1. Mekanisme Policing berbasis FIFO[3]

\subsection{Metode Berbasis Logika Fuzzy}

Pemodelan yang dibuat dalam mensimulasikan layanan GFR terhadap trafik TCP/IP terdiri dari elemen Sumber (VCi yang membawa MCRi 
masing-masing), Multiplexing and Tagging, dan Buffer Switch (dengan fuzzy rule yang mengendalikan mekanisme penempatan paket-paket di ruang buffer) seperti ditunjukkan pada Gambar 2.

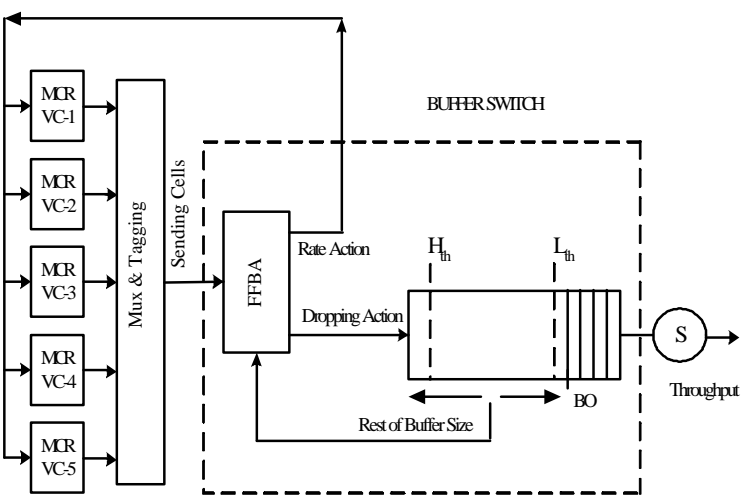

Gambar 2. Model Simulasi Layanan GFR Berbasis Logika Fuzzy [10]

Pada buffer switch terdapat elemen pengendali berbasis pada logika fuzzy yang dikenal dengan nama Fuzzy Fair Buffer Allocation (FFBA). FFBA merupakan suatu metode yang dapat melakukan pengendalian dengan memanfaatkan ruang buffer sisa sebagai umpan balik untuk melaksanakan tindakan pembuangan paket dan pengaturan rate kedatangan paket berikutnya, berdasarkan jaminan bandwidth minimumnya dan tingkat prioritas dari paket tersebut $[8,10]$. Penggunaan High Threshold $\left(\mathrm{H}_{\mathrm{th}}\right)$ dan Low Threshold $\left(\mathrm{L}_{\mathrm{th}}\right)$ dilihat sebagai indikator bagi besaran Buffer Occupancy (BO) setiap saat, sehingga berlaku ketentuan berikut :

a. Jika $B O$ ? $L_{t h}$, semua paket yang datang akan diterima (AFA - All Frame Admitted) dan kedatangan paket berikutnya diberikan dengan rate yang "Fast".

b. Jika $L_{t h},<B O<H_{t h}$, paket yang datang akan ditandai sebagai frame dengan bit CLP $=0$ dan frame dengan bit $\mathrm{CLP}=1$. Paket dengan CLP $=0$ akan diterima, sedangkan yang lain akan dibuang (CLP1D), sehingga kedatangan paket berikutnya diberikan dengan rate yang "Moderate". Penerimaan paket dengan bit CLP $=1$ masih dimungkinkan jika sumberdaya masih tersedia.

c. Jika $B O$ ? $H_{t h}$, FFBA akan membuang semua paket, kecuali paket-paket dengan bit CLP $=0$ dengan jaminan rate minimum (MinA), sehingga kedatangan paket berikutnya diberikan dengan rate yang "Slow".

Tabel 1. Aturan Dasar fuzzy

\begin{tabular}{|c|c|c|c|c|c|}
\hline \multirow{2}{*}{$\begin{array}{c}\text { Sending } \\
\text { Cell (SC) }\end{array}$} & \multicolumn{5}{|c|}{ Rest of Buffer Size (RBS) } \\
\cline { 2 - 6 } & VS & S & A & Lg & VLg \\
\hline Sh & AFA & AFA & AFA & AFA & AFA \\
\hline Av & MinA & CLP1D & AFA & AFA & AFA \\
\hline Ln & MinA & MinA & CLP1D & CLP1D & AFA \\
\hline
\end{tabular}

Metode FFBA mempunyai dua input dan dua output dengan fungsi keanggotaan input-nya adalah Rest of Buffer Size (RBS) dan jumlah dari Sending Cell (SC), sedangkan fungsi keanggotaan output-nya adalah Dropping Action (DA) dan Rate Action (RA).

Himpunan keanggotaan fuzzy untuk input RBS dan SC dapat dinyatakan sebagai berikut:

$\mathrm{T}(\mathrm{RBS})=\{$ Very Short $(\mathrm{VS})$, Short $(\mathrm{S})$, Average $(\mathrm{A})$, Long (Lg), Very Long (VLg)\}

$\mathrm{T}(\mathrm{SC})=\{$ Short $(\mathrm{Sh})$, Average (Av), Long (Ln) $\}$

Himpunan keanggotaan fuzzy untuk output DA dan RA dapat dinyatakan sebagai berikut:

$\mathrm{T}\left(\mathrm{Z}_{\mathrm{DA}}\right)=\{$ All Frame Admited (AFA),

Paket TCP dengan bit CLP=1 dibuang (CLP1D),

Paket TCP dengan bit $\mathrm{CLP}=0$ diterima

berdasarkan MCR (MinA)\}

$\mathrm{T}(\mathrm{RA})=\{$ "Slow","Moderate", "Fast" $\}$

Berdasarkan pada fungsi keanggotaan input maupun output di atas, maka dapat dibuat sebanyak 15 aturan dasar fuzzy, seperti terlihat pada Tabel 1.

Untuk mendapatkan keluaran akhir $\left(\mathrm{Z}_{\mathrm{DA}}\right)$ dalam nilai crisp, maka dilakukan proses defuzzifikasi, yaitu dengan menggunakan metode Center of Gravity (COG). Metode ini menghasilkan suatu keluaran tunggal dengan cara memilih aturan yang aktif yang memiliki nilai derajat keanggotaan minimum pada output fungsi keanggotaannya [9]. Keluaran dari defuzzifikasi ini berupa keputusan (action) yang dihitung menurut persamaan:

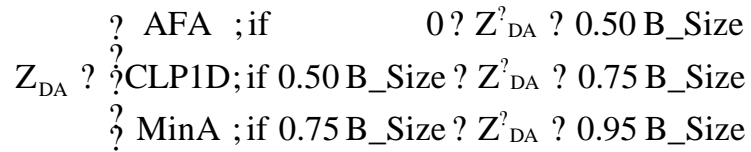

dengan:

$$
\begin{aligned}
& \mathrm{Z}_{\mathrm{DA}}^{?} \quad \stackrel{? ? ?_{D A}\left(w_{i}\right) w_{i}}{? ?_{D A}\left(w_{i}\right)} \\
& w_{i} \quad=\text { nilai kendali, } \\
& i \quad=1, \mathrm{~m} \text { (level kuantisasi), } \\
& ?_{D A} \quad: \text { fungsi keanggotaan Dropping Action }
\end{aligned}
$$

Karena itu, pengaruh mekanisme FFBA memperlihatkan bahwa semua paket akan dibuang jika penempatan buffer telah melampaui setting batas ambangnya, baik high maupun low threshold, sesuai dengan persetujuan antara user dan network. Dengan kata lain, mekanisme FFBA selalu menerima paket dengan bit $\mathrm{CLP}=0$ sebagai paket berpriotitas tinggi, dan membuang paket dengan bit $\mathrm{CLP}=1$ seawal mungkin ketika akan terjadi kongesti di jaringan. Hal lain yang menarik adalah jika rate pengiriman paket melebihi kontrak trafik MCR, maka paket akan diterima dengan rate minimum sama dengan MCR-nya. Sedangkan jika pengirimannya lebih rendah dari MCR, maka paket diterima dengan jaminan loss minimum. 


\section{Simulasi dan Analisis}

\subsection{Simulasi}

Untuk simulasi penelitian ini, dibuat buffer size berukuran $3000 \mathrm{sel}, 4000 \mathrm{sel}, 5000 \mathrm{sel}$, dan $6000 \mathrm{sel}$. Sedangkan beban trafik yang diberikan adalah beban trafik prioritas tinggi (paket dengan bit CLP=0) mulai dari $50 \%, 60 \%, 70 \%, 80 \%, 90 \%$ sampai $95 \%$, dan prosentase sisanya dinyatakan sebagai beban trafik berprioritas rendah (paket dengan bit CLP=1).

Untuk kepentingan analisis kinerja FFBA, ditentukan nilai Peak Cell Rate $(\mathrm{PCR})=155 \mathrm{Mbps}$ (367 cell/ms). Adapun batas rate sambungan trafik kontrak yang dialokasikan untuk: VC-1: 30Mbps, VC-2: 27Mbps, VC-3: 32Mbps, VC-4: 32Mbps, dan VC-5: 34Mbps. Trafik kontrak merupakan jaminan akan kebutuhan Bandwidth Minimum yang harus diberikan ketika sebuah VC mengirimkan paket TCPnya. Untuk itu dipilih nilai MCR sebagai trafik kontrak yang disepakati oleh setiap VC dengan harga 10 Mbps.

Throughput per-VC dalam simulasi ini adalah jumlah sel (paket TCP) dari masing-masing hubungan VC yang dinyatakan berhasil masuk ke dalam buffer setelah melalui manajemen buffer FFBA selama periode pengamatan, sehingga dalam grafik dinyatakan sebagai karakteristik throughput. Di samping itu, uji simulasi juga dilakukan untuk mendapatkan total throughput dan besar pendudukan buffer maksimum yang mampu dicapai oleh manajemen buffer berbasis logika fuzzy (FFBA).

\subsection{Hasil dan Diskusi}

Hasil-hasil simulasi berikut memperlihatkan kinerja manajemen buffer FFBA dan metode konvensional (Non FFBA) sebagai pembandingnya.

\subsubsection{Karakteristik Throughput}

Pada Gambar.3 diperlihatkan karakteristik throughput untuk beban trafik prioritas tinggi $50 \%$ dengan ukuran buffer 3000 sel dan 6000 sel. Pada awal simulasi diperoleh throughput masing-masing VC sesuai dengan rate kontraknya, sehingga semua paket TCP dapat memasuki buffer. Pada detik ke-2, paket-paket TCP yang masuk ke buffer sudah mulai dibatasi sesuai dengan mekanisme FFBA yang memutuskan bahwa hanya paket dengan bit CLP $=0$ akan dijamin bandwidth minimumnya. Dengan diperbesarnya ukuran buffer yaitu menjadi $6000 \mathrm{sel}$, maka mekanisme FFBA mulai melakukan fungsinya setelah detik ke-2, dan terlihat bahwa semua jaminan MCR terhadap masing-masing VC dipenuhinya. Pada Tabel 2 keadaan ini dinyatakan kondisi OK.

Tabel 2 dibuat untuk memperlihatkan betapa mekanisme FFBA dapat bekerja terhadap perubahan beban dan ukuran buffer. Karakteristik throughput dinyatakan Ok jika jaminan minimum bandwidth atau MCR terhadap setiap VC dipenuhi selama waktu simulasi. Jadi, dapat disimpulkan bahwa mekanisme FFBA mampu bekerja memenuhi jaminan bandwidth minimum dan mencegah terjadinya kongesti hingga pada beban prioritas tinggi 60\% dengan ukuran buffer 5000 sel. Waktu dalam orde detik seperti dalam Tabel menyatakan lamanya waktu Jaminan MCR dapat dipenuhi dan jaringan belum kongesti. Setelah waktu tersebut, jaminan MCR terhadap setiap VC sulit dipenuhi dan jaringan cenderung kongesti.

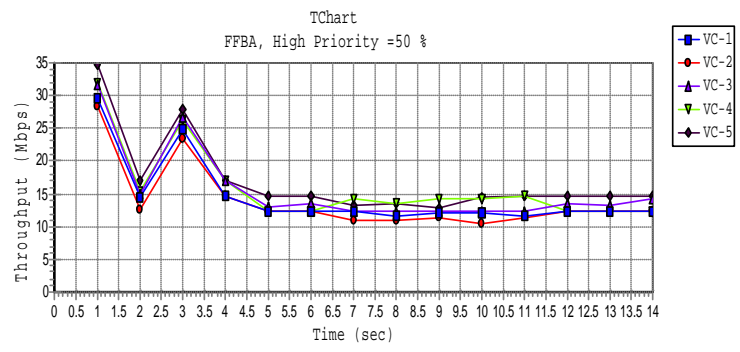

(a) Buffer Size $3000 \mathrm{sel}$

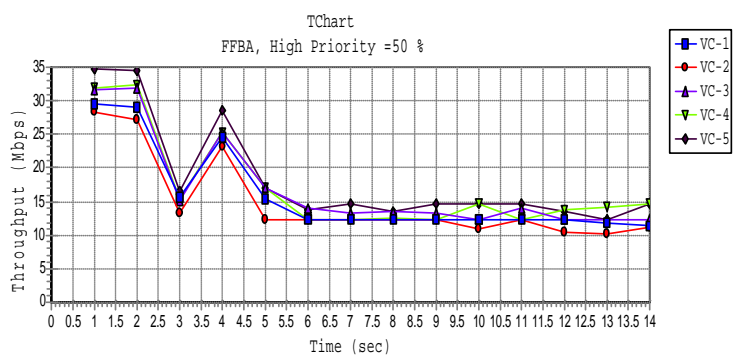

(b) Buffer Size $6000 \mathrm{sel}$

Gambar.3. Karakteristik Throughput FFBA dengan Beban Prioritas Tinggi 50\%

Tabel 2. Karakteristik Throughput FFBA terhadap Perubahan Beban Prioritas Tingggi

\begin{tabular}{|c|c|c|c|c|}
\hline $\begin{array}{c}\text { Load } \\
\text { High } \\
\text { Priority }\end{array}$ & \multicolumn{4}{|c|}{ Throughput } \\
\cline { 2 - 5 } & Buffer Size & Buffer Size & Buffer Size & Buffer Size \\
4000 sel & 4000 sel & 5000 sel & 6000 sel \\
\hline $50 \%$ & Ok & Ok & Ok & Ok \\
\hline $60 \%$ & 6 det & 13 det & Ok & Ok \\
\hline $70 \%$ & $5.5 \mathrm{det}$ & $5 \mathrm{det}$ & $12.5 \mathrm{det}$ & $12.5 \mathrm{det}$ \\
\hline $80 \%$ & $7 \mathrm{det}$ & $7.5 \mathrm{det}$ & $9.5 \mathrm{det}$ & $10.5 \mathrm{det}$ \\
\hline $90 \%$ & $5.5 \mathrm{det}$ & $6.5 \mathrm{det}$ & $8.5 \mathrm{det}$ & $8.5 \mathrm{det}$ \\
\hline $95 \%$ & $5.75 \mathrm{det}$ & $6.5 \mathrm{det}$ & $6.5 \mathrm{det}$ & $8.5 \mathrm{det}$ \\
\hline
\end{tabular}

Untuk melihat seberapa jauh mekanisme FFBA memberikan perbaikan, juga dilihat karakteristik throughput jika digunakan metode konvensional (Non Fuzzy). Gambar 4 menunjukkan Karakteristik Throughput Non FFBA untuk beban prioritas tinggi $50 \%$, dengan perubahan ukuran buffer 3000 sel dan 6000 sel. Pada ukuran Buffer 3000 sel, jaminan kecepatan minimum 10 Mbps dipenuhi hanya sampai waktu 5 detik, dan setelah itu kondisi kongesti terjadi. Setelah dilakukan penambahan beban prioritas tinggi, ternyata karakteristik throughput tidak semakin baik, sehingga jaminan MCR pada kebutuhan koneksi sulit untuk dipenuhi. 
TChart

Non FFBA, High Priority $=50 \div$

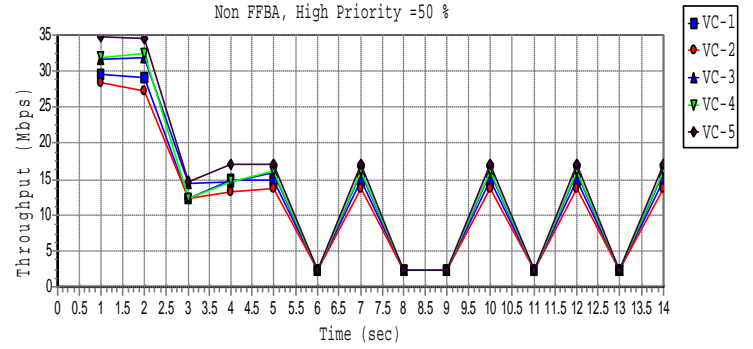

(a) Buffer Size 3000 sel

Non $\mathrm{FFBA}$, High Priority $=50 \%$

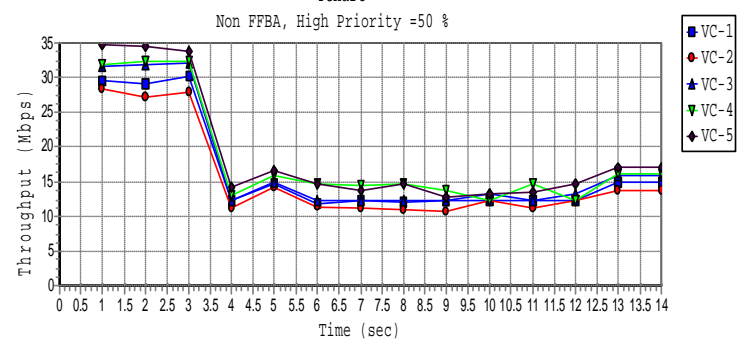

(b) Buffer Size $6000 \mathrm{sel}$

Gambar 4. Karakteristik Throughput Non FFBA dengan Beban Prioritas Tinggi 50\%

Tabel.3 Karakteristik Throughput Non FFBA terhadap Perubahan Beban Prioritas Tinggi

\begin{tabular}{|c|c|c|c|c|}
\hline \multirow{2}{*}{\begin{tabular}{|c} 
Load \\
High \\
Priority
\end{tabular}} & \multicolumn{4}{|c|}{ Throughput } \\
\hline & $\begin{array}{c}\text { Buffer Size } \\
3000 \text { sel }\end{array}$ & $\begin{array}{c}\text { Buffer Size } \\
4000 \text { sel }\end{array}$ & $\begin{array}{c}\text { Buffer Size } \\
5000 \text { sel }\end{array}$ & $\begin{array}{c}\text { Buffer Size } \\
6000 \mathrm{sel}\end{array}$ \\
\hline $50 \%$ & $5 \mathrm{det}$ & $9 \mathrm{det}$ & $10 \mathrm{det}$ & Ok \\
\hline $60 \%$ & $3 \mathrm{det}$ & $3 \mathrm{det}$ & 4 det & $4.5 \mathrm{det}$ \\
\hline $70 \%$ & $2.5 \mathrm{det}$ & $2.5 \mathrm{det}$ & $3.5 \mathrm{det}$ & $3.75 \mathrm{det}$ \\
\hline $80 \%$ & $2.5 \mathrm{det}$ & $2.75 \mathrm{det}$ & $3.75 \mathrm{det}$ & $3.75 \mathrm{det}$ \\
\hline $90 \%$ & $2.75 \mathrm{det}$ & $2.75 \mathrm{det}$ & $3.75 \mathrm{det}$ & $3.75 \mathrm{det}$ \\
\hline $95 \%$ & $2.75 \mathrm{det}$ & $2.75 \mathrm{det}$ & $3.5 \mathrm{det}$ & $3.75 \mathrm{det}$ \\
\hline
\end{tabular}

Seperti terlihat di Tabel 3, jaminan MCR untuk metode Non FFBA hanya dimungkinkan jika beban jaringan dalam kondisi rendah (50\% CLP $=0$, dan $50 \% \mathrm{CLP}=1$ ) pada ukuran buffer 6000 sel.

\subsubsection{Total Throughput}

Total throughput adalah jumlah dari throughput masing-masing $\mathrm{VC}$ yang dapat dicapai selama waktu simulasi. Evaluasi dilakukan baik untuk FFBA maupun Non FFBA.

Tabel 4 memperlihatkan total throughput yang dapat dicapai jika beban prioritas tinggi terus meningkat. Berdasarkan perhitungan, paket dengan MSS $=1024$ byte dapat mencapai total throughput maksimum 126 Mbps. Tabel 4 juga menunjukkan kemampuan metode FFBA dapat mencapai total throughput lebih dari $70 \%$ terhadap total throughput maksimumnya, jika beban trafik prioritas tinggi di atas $80 \%$ dengan ukuran buffer 6000 sel.
Tabel 4. Total Throughput pada FFBA

\begin{tabular}{|c|c|c|c|c|}
\hline Load & \multicolumn{4}{|c|}{ Total Throughput } \\
\cline { 2 - 5 } High \\
Priority & Buffer Size & Buffer Size & Buffer Size & Buffer Size \\
3000 sel & 4000 sel & 5000 sel & 6000 sel \\
\hline $50 \%$ & $75.0 \mathrm{Mbps}$ & $77.0 \mathrm{Mbps}$ & $80.0 \mathrm{Mbps}$ & $82.0 \mathrm{Mbps}$ \\
\hline $60 \%$ & $77.0 \mathrm{Mbps}$ & $83.5 \mathrm{Mbps}$ & $86.9 \mathrm{Mbps}$ & $93.5 \mathrm{Mbps}$ \\
\hline $70 \%$ & $77.1 \mathrm{Mbps}$ & $84.5 \mathrm{Mbps}$ & $87.9 \mathrm{Mbps}$ & $93.8 \mathrm{Mbps}$ \\
\hline $80 \%$ & $79.8 \mathrm{Mbps}$ & $85.1 \mathrm{Mbps}$ & $88.8 \mathrm{Mbps}$ & $94.4 \mathrm{Mbps}$ \\
\hline $90 \%$ & $80 \mathrm{Mbps}$ & $85.5 \mathrm{Mbps}$ & $91.3 \mathrm{Mbps}$ & 96.7 Mbps \\
\hline $95 \%$ & $83.5 \mathrm{Mbps}$ & $87.4 \mathrm{Mbps}$ & $91.4 \mathrm{Mbps}$ & $98.5 \mathrm{Mbps}$ \\
\hline
\end{tabular}

Tabel 5. Total Throughput pada Non-FFBA

\begin{tabular}{|c|c|c|c|c|}
\hline Load & \multicolumn{4}{|c|}{ Total Throughput } \\
\cline { 2 - 5 } High \\
Priority & Buffer Size & Buffer Size & Buffer Size & Buffer Size \\
3000 sel & 4000 sel & 5000 sel & 6000 sel \\
\hline $50 \%$ & $61.0 \mathrm{Mbps}$ & $68.6 \mathrm{Mbps}$ & $77.0 \mathrm{Mbps}$ & $80.0 \mathrm{Mbps}$ \\
\hline $60 \%$ & $60.2 \mathrm{Mbps}$ & $68.4 \mathrm{Mbps}$ & $76.8 \mathrm{Mbps}$ & $70.2 \mathrm{Mbps}$ \\
\hline $70 \%$ & $52.6 \mathrm{Mbps}$ & $57.7 \mathrm{Mbps}$ & $60.7 \mathrm{Mbps}$ & $62.8 \mathrm{Mbps}$ \\
\hline $80 \%$ & $50.1 \mathrm{Mbps}$ & $54.9 \mathrm{Mbps}$ & $58.8 \mathrm{Mbps}$ & $63.7 \mathrm{Mbps}$ \\
\hline $90 \%$ & $54.3 \mathrm{Mbps}$ & $54.6 \mathrm{Mbps}$ & $58.9 \mathrm{Mbps}$ & $60.6 \mathrm{Mbps}$ \\
\hline $95 \%$ & $50.6 \mathrm{Mbps}$ & $56.7 \mathrm{Mbps}$ & $55.1 \mathrm{Mbps}$ & $61.2 \mathrm{Mbps}$ \\
\hline
\end{tabular}

Adapun dengan metode Non FFBA, seperti terlihat pada Tabel 5, hanya dapat dicapai total throughput $60 \%$ terhadap total throughput maksimumnya. Itupun dicapai pada beban trafik prioritas tinggi hanya $50 \%$ dengan ukuran buffer 6000 sel. Dengan kata lain, metode Non FFBA tidak dapat mendukung pencapaian total throughput yang diinginkan, jika beban prioritas tinggi dinaikkan. Hal ini berbeda dengan metode FFBA yang ternyata dapat meningkatkan pencapaian nilai total throughput-nya untuk beban trafik prioritas tinggi dinaikkan, walaupun terbatas pada pencapaian mendekati $80 \%$ throughput maksimum, jika beban trafik prioritas tinggi yang diberikan terus meningkat hingga 95\% dengan ukuran buffer 6000 sel.

Jadi jika dihubungkan dengan batas waktu pemenuhan jaminan MCR yang diberikan (seperti dibahas pada sub-bagian 3.2.1), maka total throughput pada FFBA adalah 93.5 Mbps atau 75\% dari throughput maksimum-nya.

\subsubsection{Maksimum Buffer Occupancy}

Gambar.5 menunjukkan besarnya maksimum buffer occupancy yang dapat dicapai oleh mekanisme FFBA dengan meningkatkan beban prioritas tinggi secara bertahap, untuk berbagai ukuran buffer. Maksimum buffer occupancy dicapai dengan nilai tertinggi mendekati $100 \%$ pada beban CLP0 $=95 \%$, dengan ukuran buffer yg sangat efisien, yaitu cukup 3000 sel. Hal sebaliknya dapat dilihat bahwa pada beban terendah (CLP0 $=50 \%)$, maksimum buffer occupancy hanya $70 \%$, yang menunjukkan bahwa mekanisme FFBA sangat baik untuk perubahan beban trafik prioritas tinggi yang terus meningkat. 


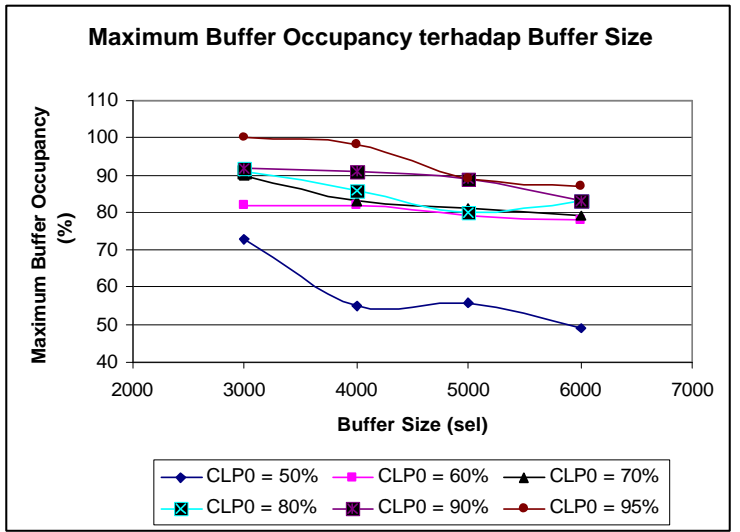

Gambar 5. Maksimum Buffer Occupancy terhadap Perubahan Ukuran Buffer untuk Metode FFBA

\section{Kesimpulan}

Dari hasil simulasi dan analisis di atas dapat diambil beberapa kesimpulan penting, antara lain:

1. Secara umum metode FFBA telah berhasil dalam mengatur penempatan paket yang dibawa oleh hubungan VC dengan jaminan MCR terhadap beban trafik prioritas tinggi dan menghindarkan dari kongesti.

2. Kemampuan metode FFBA dalam menangani beban trafik prioritas tinggi yang terus meningkat ditunjukkan oleh total throughput yang dapat mencapai sebesar $80 \%$ dari total throughput maksimumnya.

3. Karakteristik throughput dari metode FFBA memberikan jaminan MCR dan tanpa kongesti yang dapat dicapai pada beban prioritas tinggi $60 \%$ dengan ukuran buffer 4000 sel. Sedangkan dengan Non-FFBA, hal ini terpenuhi pada beban prioritas tinggi 50\% dan ukuran buffer 6000 sel.

4. Indikator Buffer Occupancy Maksimum menunjukkan bahwa mekanisme FFBA sangat tepat untuk digunakan pada kondisi beban yang dinamis, dengan kecenderungan perubahan beban prioritas tinggi terus meningkat.

\section{Daftar Pustaka}

[1] ATM Forum, ATM Traffic Management Specification Version 4.1, March 1999

[2] Bonaventure, Olivier, 1998, Integration of ATM under TCP/IP to provide services with minimum guaranteed bandwidth, Dissertation, University de Liege.

[3] Goyal, R., 1999, Buffer Management for TCP/IP over The ATM GFR Service, The Ohio State University.

[4] Goyal, R., 1999, Buffer Management for TCP/IP over Asynchronous Transfer Mode (ATM) Network, Dissertation, The Ohio State University.
[5] Goyal. R., R. Jain, et. al., Simulation Experiments with Guaranteed Frame Rate for TCP/IP Traffic, ATM Forum 97-0607.

[6] Liakopoulos, Athanassios, 1998, Simulation Experiments with Guaranteed Frame Rate for TCP Traffic over ATM Network, Dissertation, University of Surrey.

[7] Munadi, R., Dadang Gunawan, Sar Sardy, Applied Fuzzy Traffic Policer for avoiding congestion state on ATM Network, Proceeding of International Conference On Optoelectronics and Laser Application (ICOLA'02), October 2-3, 2002, Jakarta.

[8] Munadi, R., Dadang Gunawan dan Sar Sardy, Manajemen Buffer dengan Fuzzy Control Prioritas pada Jaringan ATM, Prosiding Seminar QiR ke 6 FTUI, 1 - 2 Oktober 2003.

[9] Ross, Timothy J., 1995, Fuzzy Logic with Engineering Application, McGraw-Hill Inc.

[10] Sardy, S., Rendy Munadi and Dadang Gunawan, A Buffer Management System for TCP/IP with Fuzzy Control over the ATM-GFR Service, The VIP Forum of the International Symposium SSCCII-2004, Amalfi, Italy, Jan 29 - Feb 1, 2004. 